$\begin{array}{ll}\text { Volume } & : 05 \\ \text { Nomor } & : 03 \\ \text { Bulan } & : \text { September } \\ \text { Tahun } & : 2019 \\ \text { http } & : \text { //ejurnal.pps.ung.ac.id/index.php/AKSARA/index }\end{array}$

\title{
UPAYA MENINGKATKAN HASIL BELAJAR SISWA MELALUI MODEL PEMBELAJARAN MIND MAPPING
}

\author{
Syamsudin Kasim \\ SMP Negeri 4 Kota Gorontalo \\ syamsudin@gmail.com
}

Received: 02 Juni 2019; Revised: 19 Juli 2019; Accepted: 25 Agustus 2019

\begin{abstract}
ABSTRAK
Permasalahan dalam penelitian ini apakah penggunaan model Mind Mapping dapat meningkatkan hasil belajar siswa materi iman kepada hari akhir pada pembelajaran PAI di kelas IX SMP Negeri 4 Kota Gorontalo?. Adapun tujuan penelitian ini adalah Adapun yang menjadi tujuan penelitian adalah untuk meningkatkan hasil belajar siswa pada pembelajaran PAI materi iman kepada hari akhir melalui model pembelajaran Mind Mapping di kelas IX SMPN Kota Gorontalo. Penelitian ini terdiri atas 2 siklus dengan hasil pada siklus I yaitu dari 23 orang jumlah siswa, terdapat 11 orang siswa yang yang memperoleh nilai lebih dari 75 sebanyak 52,38 $\%$. dan terjadi peningkatan pada siklus II yaitu dari 23 orang keseluruhan jumlah siswa, terdapat 22 orang siswa yang yang memperoleh nilai lebih dari 75 sebanyak 96\%. Simpulan dari Penelitian ini adalah penggunaan model Mind Mapping sangat membantu guru dalam menanamkan materi iman kepada hari akhir pada pembelajaran PAI di Kelas IX SMP Negeri 4 Kota Gorontalo.
\end{abstract}

Kata Kunci: Hasil belajar siswa dan Model Pembelajaran Mind Mapping

\section{PENDAHULUAN}

Hidup itu berjuang adalah pepatah klasik yang tetap relevan. Banyak makna yang dapat ditafsirkan dari pepatah tersebut. Dalam dunia pendidikan, Samatowa (2009:146) mengemukakan bahwa hidup itu berjuang, berarti ada hal yang diperjuangkan. Seorang pelajar harus memperjuangkan ilmu, seluruh waktu dan pikirannya dikonsentrasikan untuk mendapatkan ilmu. Salah satu wadah tempat perjuangan seorang pelajar dalam mencari jatidiri dan perubahan perilakunya adalah sekolah. Sekolah merupakan lembaga pendidikan formal pada dasarnya bertujuan untuk mencerdaskan peserta didik atau siswa melalui proses belajar mengajar di kelas. Para siswa masuk sekolah mengikuti program pendidikan diduga terlibat dalam kegiatan belajar. Mencermati hal ini, menyajikan pembelajaran PAI wajib mengantarkan siswa ke hal-hal yang lebih bermakna terutama materi yang dijadikan bahan penelitian ini yaitu iman kepada hari akhir. Oleh karena itu, strategi yang paling cocok berdasarkan pengamatan yang akan diformat dalam penelitian ini dapat digunakan oleh guru untuk mengakomodasi seluruh keunikan karakteristik siswa adalah dengan menggunakan model Mind Mapping. Dengan adanya pembelajaran yang menggunakan model ini, diharapkan perhatian dan respon siswa akan terus dipelihara karena mereka diarahkan untuk memecahkan persoalan dalam bentuk pemetaan terstruktur.

Mind mapping dapat dipahami sebagai suatu strategi untuk mencatat yang kreatif dan efektif, dan secara harfiah akan memetakan pikiran-pikiran kita. Manfaat awal mind mapping adalah untuk mencatat. Mind mapping dapat menggantikan metode lama outlining yang kaku dan kadang mengganggu kebebasan memunculkan ide-ide baru. Mind mapping juga merupakan peta rute yang hebat bagi ingatan, memungkinkan seseorang menyusun fakta dan pikiran sedemikian rupa sehingga cara kerja alami otak dilibatkan sejak awal. Ini berarti mengingat informasi akan lebih mudah dan lebih bisa diandalkan daripada menggunakan teknik 


$\begin{array}{ll}\text { Volume } & : 05 \\ \text { Nomor } & : 03 \\ \text { Bulan } & : \text { September } \\ \text { Tahun } & : 2019 \\ \text { http } & : / / \text { ejurnal.pps.ung.ac.id/index.php/AKSARA/index }\end{array}$

pencatatan konvensional. Dengan demikian daftar informasi yang panjang bisa dialihkan menjadi diagram warna-warni, sangat teratur, dan mudah diingat yang bekerja selaras dengan cara kerja alami otak.

Berdasarkan fakta di lapangan khususnya di kelas IX SMP Negeri 4 Kota Gorontalo pada pembelajaran PAI, ternyata guru belum tepat memilih model pembelajaran bahkan belum mengetahui peran model yang dikaji dalam penelitian ini. Hasil observasi awal menunjukkan bahwa dari 23 orang siswa yang belum memiliki hasil belajar yang baik adalah 57\% atau 13 orang, sedangkan yang telah mencukupi standar belajar yang ditetapkan hanya berkisar $43 \%$ atau 10 orang.

\section{KAJIAN TEORITIS DAN HIPOTESIS TINDAKAN Pengertian Belajar}

Belajar merupakan proses suatu adaptasi yang berlangsung sebagai proses yang disebabkan oleh pengalaman. Para ahli memiliki pandangan berbeda tentang konsep belajar. Slameto (2010:2) memandang bahwa belajar merupakan suatu proses usaha yang dilakukan individu untuk memperoleh suatu perubahan tingkah laku yang baru secara keseluruhan, sebagai hasil pengalaman individu itu sendiri dalam interaksi dengan lingkungannya. Skinner dalam akhmadlabib (2010:14) mengemukakan bahwa belajar adalah perilaku. Hal-hal yang mempengaruhi naik turunnya respon belajar adalah; (a) Kesempatan terjadinya peristiwa yang menimbulkan respon belajar, (b) Respon si pembelajar, (c) Konsekuensi yang bersifat menguatkan respon tersebut.

\section{Fungsi belajar}

Djamarah dan Zain (2010:42) mengemukakan bahwa fungsi belajar dapat dijabarkan sebagai berikut:

a. Fungsi Normatif, yaitu sejumlah nilai karakter yang didapat oleh siswa dari proses belajar

b. Fungsi Kompas, yaitu sebagai pedoman untuk melakukan sebuah perubahan

c. Fungsi pengajaran, merupakan perwujudan aspek kognitif siswa

Berdasarkan pendapat ahli tersebut, maka dapat disimpulkan bahwa belajar pada dasarnya memiliki fungsi untuk perubahan tingkah laku siswa.

\section{Definisi Hasil belajar}

Mengkaji tentang hasil belajar, tentunya kita membahas dulu definisi dari minat itu sendiri. Sujanto (dalam Amalia, 2012:2) mengemukakan bahwa Minat adalah sesuatu pemusatan perhatian yang tidak disengaja yang lahir dengan penuh kemauannya dan yang tergantung dari bakat dan lingkungannya. Fazri (2008:58) memandang bahwa minat merupakan keinginan yang kuat serta kecenderungan hati yang sangat tinggi terhadap sesuatu.

Slameto (2010:180) mengemukakan bahwa minat adalah suatu rasa lebih suka dan rasa keterikatan pada suatu hal atau aktivitas, tanpa ada yang menyuruh. Minat pada dasarnya adalah penerimaan akan suatu hubungan antara diri sendiri dengan sesuatu di luar diri. Semakin kuat atau dekat hubungan itu, maka semaikn besar minat.

\section{Pembelajaran PAI tentang hari Akhir}

Pembelajaran hari akhir erat kaitannya dengan aqidah. Hal ini sebagaimana ditegaskan oleh Nasution (2000:30) yaitu Secara syara' Aqidah yaitu iman kepada Allah, para malaikatnya, kitab-kitabnya, para rasulnya dan kepada hari akhir serta kepada Qadar yang baik maupun yang buruk. Pendapat tersebut sejalan dengan pemikiran Syaddad (2014:3) yang mengemukakan bahwa Hari akhir atau hari kiamat adalah hari berakhirnya seluruh proses kehidupan makhluk hidup di dunia. Beriman kepada hari akhir (hari kiamat) artinya mempercayai dengan sepenuh 


$\begin{array}{ll}\text { Volume } & : 05 \\ \text { Nomor } & : 03 \\ \text { Bulan } & : \text { September } \\ \text { Tahun } & : 2019 \\ \text { http } & : \text { //ejurnal.pps.ung.ac.id/index.php/AKSARA/index }\end{array}$

hati bahwa hari kiamat itu pasti akan datang dan seluruh ummat manusia akan kembali dibangkitkan dari alam kubur untuk menerima pengadilan dari Allah swt sebagai hakim yang Maha Adil.

\section{Hakikat Model Mind Mapping}

Pada dasarnya model ini sudah tidak asing lagi ditelinga kita, namun sebagian besar pendidik dan calon pendidik kurang memahami tentang prosedur dan manfaatnya. Hisyam Zaini, dkk (2007:168) mengemukakan bahwa Mind mapping (peta konsep) merupakan strategi yang meminta peserta didik mensintesis atau membuat satu gambar atau diagram tentang konsep-konsep utama yang saling berhubungan, yang ditandai dengan garis panah di tulis level yang membunyikan bentuk hubungan antar konsep-konsep utama.

Bobbi DePorter dan Mike Hernacki (2002:153) mengemukakan bahwa mind mapping adalah teknik pemanfaatan keseluruhan otak dengan menggunakan citra visual dan prasarana grafis lainnya untuk membentuk kesan Konsep merupakan dasar untuk berfikir, untuk belajar aturan aturan dan akhirnya untuk memecahkan masalah. Dengan demikian itu sangat penting bagi peserta didik. Misalnya dalam pembelajaran mind mapping (peta konsep) dapat dijadikan sebagai alternatif dalam pembelajaran, karena dengan adanya pemetaan dapat mempermudah peserta didik untuk mempelajari materi tersebut.

Disisi lain Trianto (2007:159) mengemukakan bahwa untuk membuat suatu mind mapping (peta konsep), peserta didik dilatih untuk mengidentifikasi ide-ide kunci yang berhubungan dengan suatu topik dan menyusun bentuk-bentuk tersebut dalam bentuk suatu pola.

\section{Langkah-langkah Penggunaan Model Mind Mapping pada Pembelajaran Iman Kepada hari Akhir}

Penyusunan mind mapping (peta konsep) berbeda dengan mencatat, tetapi ada beberapa hal yang hampir sama. Pada mind mapping (peta konsep) tidak semua penjelasan dari guru atau isi dari buku pelajaran yang dipahami di catat semua. Maksudnya bahwa mind mapping (peta konsep) bisa berupa catatan ringkasan dari suatu pelajaran tetapi berbentuk pemetaan seperti bagan, grafik dan lain-lain mengenai suatu pelajaran. Manfaat awal mind mapping adalah untuk mencatat. Mind mapping dapat menggantikan metode lama outlining yang kaku dan kadang mengganggu kebebasan memunculkan ide-ide baru. De Porter dan Hernacki dalam buku Quantum Learning (2002:152) menempatkan kegiatan mencatat sebagai salah satu kegiatan terpenting dalam pembelajaran, karena selain dapat meningkatkan daya ingat, catatan juga diperlukan untuk mengingat apa yang tersimpan di dalam memori. Tanpa mencatat dan mengulang, kebanyakan peserta didik hanya mampu mengingat sebagian kecil materi yang mereka baca dan dengar.

Terkait dengan hal tersebut, Trianto (2007:159) mengemukakan bahwa Ada beberapa langkah untuk membuat atau menyusun mind mapping (peta konsep), yaitu:

a. Memilih suatu bahan bacaan.

b. Menentukan konsep-konsep yang relevan.

c. Mengelompokkan (mengusulkan konsep-konsep yang relevan).

d. Menyusun konsep-konsep tersebut dalam suatu bagan.

e. Menghubungkan konsep-konsep itu dengan kata atau menggunakan kata penghubung

\section{METODE PENELITIAN}

Penelitian ini merupakan suatu Penelitian Tindakan Kelas (PTK) yang dilaksanakan di kelas IX SMP Negeri 4 Kota Gorontalo tahun 2013.Waktu penelitian direncanakan selama 3 bulan yaitu bulan Februari s/d April 2017. 


$\begin{array}{ll}\text { Volume } & : 05 \\ \text { Nomor } & : 03 \\ \text { Bulan } & : \text { September } \\ \text { Tahun } & : 2019 \\ \text { http } & : / / \text { ejurnal.pps.ung.ac.id/index.php/AKSARA/index }\end{array}$

Adapun yang menjadi subyek dalam penelitian ini adalah siswa kelas IX dengan jumlah siswa 23 orang dengan karakteristik dan kemampuan kognitif yang berbeda.

Adapun variabel yang menjadi sasaran penelitian tindakan kelas ini guna menjawab permasalahan penelitian adalah sebagai berikut :

a) Variabel Input berupa rencana pelaksanaan pembelajaran (RPP), Lembar kerja siswa (LKS), Format pengamatan kegiatan guru dan siswa dan format pengamatan hasil belajar siswa setiap siklus

b) Variabel proses berupa proses pembelajaran dengan menggunakan model Mind Mapping.

c) Variabel Output berupa meningkatnya hasil belajar siswa yang diukur melalui instrumen tes penelitian

\section{Prosedur Pengumpulan Data}

Persiapan

Adapun hal-hal yang dilakukan pada langkah ini adalah sebagai berikut :

a) Menghadap Kepala Sekolah tempat penelitian untuk dapat diberikan kesempatan melaksanakan penelitian tindakan kelas.

b) Mengadakan observasi dan wawancara dengan pihak yang terkait pada pelaksanaan tindakan.

c) Menyusun rencana pembelajaran dan menyiapkan alat bantu/media pembelajaran

d) Merancang alat evaluasi

\section{Pelaksanaan Tindakan}

Jika tahap persiapan sudah matang, maka tahap berikutnya adalah pelaksanaan tindakan, yaitu menetapkan dan melaksanakan tindakan berdasarkan rencana yang telah ditetapkan. Apabila tidak menunjukan hasil yang diharapkan, maka diadakan peninjauan kembali terhadap prosedur serta merumuskan rencana perbaikan/penyempurnaan yang akan dilaksanakan pada siklus berikutnya.

\section{Siklus I}

a. Mengadakan apersepsi (Pre test)

b. Melaksanakan pembelajaran dengan penerapan model Mind Mapping pada pembelajaran PAI materi iman kepada hari akhir

c. Memantau proses pembelajaran

d. Melaksanakan teks akhir

e. Melaksanakan analisis dan refleksi.

\section{Siklus II}

Pelaksanaan kegiatan pada siklus II jika kegiatan pada siklus I belum berhasil. Adapun kegiatan yang dilakukan pada siklus II adalah

a) Merumuskan tindakan baru dengan mengacu pada ketetapan yang telah dibahas pada saat refleksi dengan guru se-profesi

b) Melaksanakan pembelajaran dengan menggunakan model Mind Mapping pada pembelajaran PAI materi iman kepada hari akhir

c) Memantau proses pembelajaran

d) Melaksanakan teks akhir

e) Melaksanakan analisis dan refleksi.

\section{Pemantauan dan Evaluasi}

Pada tahap ini dilakukan proses pemantauan oleh guru mitra selaku Observer dan dilakukan oleh peneliti juga terhadap pelaksanaan tindakan dengan menggunakan lembar observasi yang telah disediakan. Selanjutnya bersama guru mitra mengevaluasi hasil pemantauan yang telah dilakukan, dan untuk evaluasi hasil belajar siswa dilakukan pada tahap akhir setiap siklus yang diberikan dalam bentuk tulisan. 


$\begin{array}{ll}\text { Volume } & : 05 \\ \text { Nomor } & : 03 \\ \text { Bulan } & : \text { September } \\ \text { Tahun } & : 2019 \\ \text { http } & : \text { //ejurnal.pps.ung.ac.id/index.php/AKSARA/index }\end{array}$

\section{Analisis dan refleksi}

Setelah tahap pelaksanaan tindakan kelas dan pemantauan terhadap kegiatan pembelajaran, maka peneliti akan menganalisis hasil belajar siswa yang diperoleh dari tes dan kegiatan pembelajaran. Dari hasil analisa terhadap hasil belajar siswa dan kegiatan pembelajaran, tim peneliti dapat menyimpulkan sejauh mana hasil pelaksanaan tindakan telah mencapai indikator kinerja sehingga hipotesis tindakan dapat diterima.

\section{Teknik Pengumpulan Data}

Untuk mencari data dalam penelitian ini, peneliti menggunakan beberapa teknik pengumpulan data antara lain:

a. Observasi

Merupakan teknik pengumpulan data yang dilakukan dengan cara mengamati dan mencatat hal-hal penting yang terjadi pada saat proses kegiatan belajar mengajar berlangsung. b. Tes

Teknik ini berupa pemberian tes yang digunakan untuk mengukur peningkatan hasil belajar siswa.

c. Dokumentasi

Teknik ini berupa pendokumentasian hasil-hasil observasi dalam penelitian serta instrument yang digunakan.

\section{Teknik Analisis Data}

Dalam menganalisis kemampuan siswa dalam meningkatkan hasil belajar siswa pada materi iman kepada hari akhir melalui model Mind Mapping digunakan berupa tes tertulis dan soal uraian dengan menggunakan batas skor berdasarkan prosentase dalam indikator kinerja.

\section{HASIL PENELITIAN DAN PEMBAHASAN \\ Deskpripsi Hasil Penelitian \\ Deskripsii Siklus I}

Pada proses tindakan siklus I ini dilakukan kegiatan pembelajaran dengan menekankan pada penggunaan Model Mind Mapping. Data yang diperoleh dalam penelitian ini adalah data tentang pelaksanaan pembelajaran dengan model pembelajaran Mind Mapping pada siswa kelas IX semester II di SMPN 4 Kota Gorontalo. Hasil kegiatan ini dapat dijabarkan sebagai berikut:

1. Perencanaan

Perencanaan yang dilakukan pada siklus I ini adalah :

- Menyiapkan rencana pelaksanaan pembelajaran materi iman kepada hari akhir siswa kelas IX semester II.

- Menyiapkan perencanaan tindakan meliputi :

a. Menyiapkan lembar kerja siswa

b. Menyiapkan kegiatan awal pembelajaran, kegiatan inti pelajaran, dan akhir pembelajaran.

c. Menyiapkan lembar observasi untuk pelaksanaan observasi siswa dan guru

d. Menyiapkan format pengamatan minat

e. Menyiapkan instrumen tes

\section{Pelaksanaan Tindakan}

Pada awal kegiatan pembelajaran guru memulai pembelajaran dengan salam dan menyapa siswa, guru berusaha menarik perhatian dan minat siswa dengan sesekali mengajukan pertanyaan pelacak kepada siswa. Kemudian guru memberikan apersepsi. Tapi sebelum dimulai pembelajaran siswa diberi pertanyaan lisan untuk menjajaki sampai dimana tingkat 


$\begin{array}{ll}\text { Volume } & : 05 \\ \text { Nomor } & : 03 \\ \text { Bulan } & : \text { September } \\ \text { Tahun } & : 2019 \\ \text { http } & : \text { //ejurnal.pps.ung.ac.id/index.php/AKSARA/index }\end{array}$

pengetahuan siswa terhadap materi yang akan dipelajari dan guru sambil menjelaskan tujuan pembelajaran serta relevansinya.

Pada kegiatan inti pembelajaran guru langsung menjelaskan materi dan menerapkan srategi yang telah disiapkan yaitu model pembelajaran Mind Mapping yaitu (a) materi iman kepada hari akhir dipilih dan dijadikan sebagai bahan evaluasi atau assessment. (b) Meminta peserta didik melakukan brain storming (curah gagasan) tentang masalah atau topik atau teks atau wacana itu sebanyak mungkin (25-40 konsep). Karena bagaimanapun ketika suatu topik dibahas oleh beberapa orang akan lebih mudah. (c). Kemudian, meminta peserta didik memilih 10-12 konsep-konsep utama di atas kartu-kartu secara terpisah. (d). Meminta kembali peserta didik untuk menuliskan konsep-konsep utama di atas kartu-kartu secara terpisah. Kemudian dengan kartu-kartu yang telah bertuliskan konsep utama, mintalah peserta didik untuk mencoba beberapa kali membuat satu gambar yang saling berhubungan antar konsep-konsep. Mind mapping (peta konsep) bisa dalam bentuk vertikal atau horisontal. Mungkin juga peserta didik meletakkan konsep yang paling besar di tengah gambar. (f). Memastikan peserta didik membuat garis penghubung antar konsep konsep utama. (g). Sebelum mengakhiri tugas peserta didik, meminta mereka menulis satu kata atau level di atas setiap garis penghubung. (h). Tampilkan satu mind mapping (peta konsep) yang di buat oleh guru sebagai bahan perbandingan dengan apa yang dikerjakan peserta didik. (i). Setelah peserta didik mengerjakan tugas, selanjutnya guru melakukan koreksi atau evaluasi. (j). Setelah dikoreksi mind mapping (peta konsep) tersebut dikembalikan kepada peserta didik. (k) Sebelum mengakhiri kegiatan pembelajaran guru dan siswa menyimpulkan pelajaran yang telah dipelajari secara bersama. (l) Pada akhir kegiatan pembelajaran guru meminta siswa untuk mengerjakan lembar post tes sambil mengingatkan pelajaran yang akan dipelajari di pertemuan berikutnya. Karena waktu yang sedikit sehingga siswa tidak bisa menyelesaikan soal post tes secara maksimal. (m) Kemudian guru menutup pelajaran dengan salam dan doa.

3. Pengamatan dan Evaluasi

Pada tahap ini, peneliti bekerjasama dengan guru mitra melakukan pengamatan terhadap kegiatan guru dalam hal ini peneliti yang melaksanakan tindakan perbaikan pengajaran dengan menerapkan model pembelajaran Mind Mapping. Selain itu pula kegiatan dan hasil siswa juga tidak luput dari pengamatan guru mitra sebagai langkah untuk mengevaluasi minta belajar siswa pada pembelajaran PAI materi iman kepada hari akhir di kelas IX SMPN 4 Kota Gorontalo.

Untuk kegiatan guru sebagai mitra pada pelaksanaan tindakan, dalam hal ini Meningkatkan Hasil belajar siswa Materi iman kepada hari akhir Pada Pembelajaran PAI Melalui Model Mind Mapping dapat dilihat pada tabel berikut:

Tabel 4.2 Hasil Pengamatan Kegiatan Guru Pada Siklus I

\begin{tabular}{|c|c|c|}
\hline \multicolumn{2}{|c|}{ Kegiatan Guru } & Prosentase \\
\hline Kualifikasi & Jumlah & $(\mathbf{\% )}$ \\
\hline Sangat Baik & 0 & 0.00 \\
\hline Baik & 4 & 19 \\
\hline Cukup & 10 & 45 \\
\hline Kurang & 8 & 36 \\
\hline Jumlah & $\mathbf{2 2}$ & $\mathbf{1 0 0}$ \\
\hline
\end{tabular}

Olahan Data Primer: SMPN 4 Kota Gorontalo,2017

Berdasarkan tabel 4.2 tentang kegiatan guru dalam meningkatkan hasil belajar siswa melalui model Mind Mapping diperoleh data sebagai berikut:

a) Dari 22 aspek yang dinilai dalam proses pembelajaran, terdapat 4 aspek atau $19 \%$ yang memperoleh kriteria baik 


$\begin{array}{ll}\text { Volume } & : 05 \\ \text { Nomor } & : 03 \\ \text { Bulan } & : \text { September } \\ \text { Tahun } & : 2019 \\ \text { http } & : \text { //ejurnal.pps.ung.ac.id/index.php/AKSARA/index }\end{array}$

b) Dari 22 aspek yang dinilai dalam proses pembelajaran, terdapat 10 aspek atau $45 \%$ yang memperoleh nilai cukup.

c) Dari 22 aspek yang dinilai dalam proses pembelajaran, terdapat 8 aspek atau $36 \%$ yang memperoleh nilai kurang.

Di samping itu pula, untuk data berupa aktivitas siswa dapat dilihat pada tabel berikut ini:

Tabel 4.3 Lembar Aktivitas Siswa

Siklus I

\begin{tabular}{|c|c|c|}
\hline \multicolumn{2}{|c|}{ Aktivitas Siswa } & Prosentase \\
\hline Kualifikasi & Jumlah & $(\mathbf{\%})$ \\
\hline Baik Sekali & 0 & 0 \\
\hline Baik & 1 & 4,35 \\
\hline Cukup & 10 & 43,48 \\
\hline Kurang & 12 & 52,17 \\
\hline Jumlah & $\mathbf{2 3}$ & $\mathbf{1 0 0}$ \\
\hline
\end{tabular}

Olahan Data Primer: SMPN 4 Kota Gorontalo,2017

Berdasarkan tabel 4.3 di atas, dapat dijelaskan bahwa aktivitas siswa dalam pembelajaran PAI materi iman kepada hari akhir pada pembelajaran PAI melalui model Mind Mapping, yaitu:

1) Dari 23 aspek yang diamati, terdapat 1 aspek yang memiliki aktivitas memuaskan atau sekitar $4,35 \%$

2) Dari 23 aspek yang diamati, terdapat 22 aspek atau 95,65\% yang masih dibawah standar. Adapun data tentang hasil belajar siswa disajikan pada tabel berikut ini:

Tabel 4.4 Data Hasil Evaluasi Tindakan Siklus I

\begin{tabular}{||c|c|c|c||}
\hline No & Jumlah Siswa & Nilai & Keterangan \\
\hline 1 & 1 Orang & 47 & Tidak tuntas \\
\hline 2 & 1 Orang & 55 & Tidak tuntas \\
\hline 3 & 3 Orang & 60 & Tidak tuntas \\
\hline 4 & 1 Orang & 63 & Tidak tuntas \\
\hline 5 & 1 Orang & 64 & Tidak tuntas \\
\hline 6 & 3 Orang & 70 & Tidak tuntas \\
\hline 7 & 5 Orang & 75 & Tuntas \\
\hline 8 & 2 Orang & 80 & Tuntas \\
\hline 9 & 2 Orang & 85 & Tuntas \\
\hline 10 & 4 Orang & 90 & $100 \%$ \\
\hline & 23 Orang & & \\
\hline
\end{tabular}

\section{Olahan Data Primer: SMPN 4 Kota Gorontalo,2017}

Berdasarkan tabel 4.4 hasil evaluasi siswa dalam memahami materi iman kepada hari akhir, dapat dijelaskan bahwa:

a) Dari 23 orang jumlah siswa, terdapat 10 orang siswa yang yang memperoleh nilai kurang dari 75 atau sebanyak $47,62 \%$ 


$\begin{array}{ll}\text { Volume } & : 05 \\ \text { Nomor } & : 03 \\ \text { Bulan } & : \text { September } \\ \text { Tahun } & : 2019 \\ \text { http } & : / / \text { ejurnal.pps.ung.ac.id/index.php/AKSARA/index }\end{array}$

b) Dari 23 orang jumlah siswa, terdapat 11 orang siswa yang yang memperoleh nilai lebih dari 75 sebanyak $52,38 \%$.

Dengan demikian, maka perlu diadakan pembenahan pada siklus berikutnya dengan memperhatikan tilikan dalam refleksi.

4. Analisis dan Refleksi

Analisis dan refleksi dilakukan untuk mengetahui apakah data yang diperoleh menunjukkan apakah ada peningkatan atau tidak tentang hasil belajar siswa terhadap pembelajaran PAI materi iman kepada hari akhir menggunakan model pembelajaran Mind Mapping serta solusi dan upaya yang dilakukan untuk memecahkan masalah tersebut.

Dari hasil pengamatan yang dilakukan peneliti dan dibantu fasilitator menyimpulkan bahwa dalam pelaksanaan siklus I ini pada dasarnya sudah berjalan sesuai rencana pembelajaran meskipun belum berjalan sesuai harapan. Karena ada beberapa hal yang perlu disikapi dan dijadikan masukan untuk siklus selanjutnya. Sesuai hasil analisis dan refleksi, ditemukan beberapa beberapa hal yang menyebabkan tidak tercapainya peningkatan hasil belajar siswa pada pembelajaran PAI materi iman kepada hari akhir melalui model Mind Mapping di kelas IX SMPN 4 Kota Gorontalo dari dua faktor yaitu:

1. Faktor guru meliputi; (a) Penggunaan model Mind Mapping belum efektif, (b) Pembelajaran cenderung guru yang lebih agresif dibanding siswa, (c) Pembagian kelompok belum sempurna, (d) Belum maksimalnya pemberian tugas, (e) alokasi waktu yang tidak sesuai dengan pembelajaran, (f) Langkah-langkah kegiatan belajar mengajar dalam menggunakan model Mind Mapping belum efektif dan efisien, (g) Penyimpulan materi belum efisien;

2. Faktor siswa meliputi; (a) kurangnya motivasi dan controling, sehingga sebagian siswa hanya bertindak sesuka hati, (b) Pada saat pembagian kelompok, sebagian siswa hanya mau berkelompok dengan teman akrabnya, (c) pemecahan masalah belum efektif, (d) dalam kerja kelompok, masih terdapat beberapa orang siswa yang tidak aktif, (e) ketertiban kelas belum nampak, karena pada saat pembagian kelompok banyak siswa yang keluar - masuk ruangan tanpa seizin guru.

Berdasarkan hasil refleksi guru sebagai mitra kerja, bahwa untuk memperbaiki kelemahan-kelemahan yang terjadi pada pelaksanaan tindakan pada siklus I dalam meningkatkan hasil belajar siswa pada materi iman kepada hari akhir melalui model Mind Mapping, maka akan disempurnakan pada pelaksanaan tindakan siklus berikutnya, yaitu pelaksanaan tindakan siklus II melalui beberapa solusi diantaranya; (1) memperbaiki prosedur pelaksanaan model Mind Mapping, (2) guru lebih jeli dalam membagi kelompok, diusahakan pembagian kelompok menjadi heterogen, (3) Guru memberikan reward kepada kelompok yang berprestasi dan aktif, (4) melibatkan siswa secara aktif dalam pemecahan masalah dan penyimpulan materi, (5) mengadakan inovasi dalam pembelajaran, sehingga lebih menyenangkan.

\section{Deskripsii Siklus II}

Kegiatan tindakan siklus II dilakukan dengan alokasi waktu 2 x 40 menit meliputi:

1. Perencanaan

Perencanaan yang dilakukan pada siklus II ini adalah

- Menyiapkan rencana pembelajaran materi iman kepada hari akhir siswa kelas IX

- Menyiapkan lembar post tes,

- Menyiapkan kegiatan awal pembelajaran, kegiatan inti pelajaran dan akhir pembelajaran.

- Menyiapkan lembar observasi untuk pelaksanaan observasi

- Menyiapkan refleksi.

2. Pelaksanaan Tindakan 


$\begin{array}{ll}\text { Volume } & : 05 \\ \text { Nomor } & : 03 \\ \text { Bulan } & : \text { September } \\ \text { Tahun } & : 2019 \\ \text { http } & : \text { //ejurnal.pps.ung.ac.id/index.php/AKSARA/index }\end{array}$

Pada pelaksanaan tindakan siklus ini suasana kelompok sudah terkondisikan dan siswa sudah tahu akan hal apa yang ditugaskan. Ini ditandai dengan kesungguhan melaksanakan tugas dan meyelesaikan post tes tepat waktu. Namun tetap saja ada sebagian kecil siswa yang belum memahami model yang diterapkan

3. Pengamatan dan evaluasi

Adapun hasil pengamatan kegiatan guru dan siswa pada pelaksanaan tindakan dalam hal ini meningkatan hasil belajar siswa dengan menggunakan model Mind Mapping pada mata pelajaran PAI materi iman kepada hari akhir di kelas IX SMPN 4 Kota Gorontalo dapat dilihat pada beberapa tabel berikut ini

\section{Tabel 4.5 Pengamatan Kegiatan Guru Pada Siklus II}

\begin{tabular}{|c|c|c|}
\hline \multicolumn{2}{|c|}{ Kegiatan Guru } & Prosentase \\
\hline Kualifikasi & Jumlah & $(\mathbf{\%})$ \\
\hline Sangat Baik & 10 & 45,45 \\
\hline Baik & 11 & 50,00 \\
\hline Cukup & 1 & 4,54 \\
\hline Kurang & 0 & 0.00 \\
\hline Jumlah & $\mathbf{2 2}$ & $\mathbf{1 0 0 . 0 0}$ \\
\hline
\end{tabular}

Olahan Data Primer: SMPN 4 Kota Gorontalo, 2017

Berdasarkan tabel 4.6 tentang kegiatan guru dalam meningkatkan hasil belajar siswa, diperoleh data sebagai berikut:

1) Dari 22 aspek yang dinilai dalam proses pembelajaran, terdapat 10 aspek atau $45,45 \%$ yang memperoleh kriteria sangat baik.

2) Dari 22 aspek yang dinilai dalam proses pembelajaran, terdapat 11 aspek atau $50 \%$ yang memperoleh nilai baik.

3) Dari 22 aspek yang dinilai dalam proses pembelajaran, terdapat 1 aspek atau 94,54\% yang memperoleh nilai cukup.

Untuk data berupa aktivitas siswa dapat dilihat pada tabel berikut ini:

Tabel 4.6 Lembar Aktivitas Siswa

Siklus II

\begin{tabular}{|c|c|c|}
\hline \multicolumn{2}{|c|}{ Aktivitas Siswa } & Prosentase \\
\hline Kualifikasi & Jumlah & $(\mathbf{\%})$ \\
\hline Baik Sekali & 10 & 43,48 \\
\hline Baik & 13 & 56,52 \\
\hline Cukup & 0 & 0 \\
\hline Kurang & 0 & 0 \\
\hline Jumlah & $\mathbf{2 3}$ & $\mathbf{1 0 0}$ \\
\hline
\end{tabular}

Olahan Data Primer: SMPN 4 Kota Gorontalo,2017

Berdasarkan tabel 4.7 di atas, dapat dijelaskan bahwa aktivitas siswa dalam pembelajaran PAI materi iman kepada hari akhir dengan menggunakan model Mind Mapping, yaitu:

1). Dari 23 aspek yang diamati, terdapat 23 orang siswa yang memiliki aktivitas memuaskan atau sekitar $100 \%$

2) Dari 23 aspek yang diamati, terdapat 0 orang siswa atau $0 \%$ yang masih dibawah standar. 


$\begin{array}{ll}\text { Volume } & : 05 \\ \text { Nomor } & : 03 \\ \text { Bulan } & : \text { September } \\ \text { Tahun } & : 2019 \\ \text { http } & : \text { //ejurnal.pps.ung.ac.id/index.php/AKSARA/index }\end{array}$

Dari kegiatan guru dan siswa, diperoleh data tentang hasil belajar siswa disajikan pada tabel berikut ini:

Tabel 4.7 Data Hasil Evaluasi Tindakan Siklus II

\begin{tabular}{||c|c|c|c||}
\hline No & Jumlah Siswa & Nilai & Keterangan \\
\hline 1 & 1 Orang & 70 & Tidak tuntas \\
\hline 2 & 3 Orang & 75 & Tuntas \\
\hline 3 & 2 Orang & 80 & Tuntas \\
\hline 4 & 1 Orang & 83 & Tuntas \\
\hline 5 & 1 Orang & 85 & Tuntas \\
\hline 6 & 1 Orang & 86 & Tuntas \\
\hline 7 & 1 Orang & 88 & Tuntas \\
\hline 8 & 1 Orang & 89 & Tuntas \\
\hline 9 & 5 Orang & 90 & Tuntas \\
\hline 10 & 2 Orang & 95 & Tuntas \\
\hline 11 & 5 Orang & 100 & $100 \%$ \\
\hline & 23 Orang & & \\
\hline
\end{tabular}

\section{Olahan Data Primer: SMPN 4 Kota Gorontalo,2017}

Berdasarkan tabel 4.9 hasil evaluasi siswa dalam memahami materi iman kepada hari akhir, dapat dijelaskan bahwa:

a) Dari 23 orang keseluruhan jumlah siswa, terdapat 1 orang siswa yang yang memperoleh nilai kurang dari 75 atau sebanyak $4 \%$

b) Dari 23 orang keseluruhan jumlah siswa, terdapat 22 orang siswa yang yang memperoleh nilai lebih dari 75 sebanyak $96 \%$.

4. Analisis dan Refleksi

Setelah melaksanakan tindakan pada siklus II, dalam hal ini guru memberikan pelaksanaan tindakan siklus II dengan tujuan agar hasil belajar siswa pada materi iman kepada hari akhir pada pembelajaran PAI untuk siswa kelas IX bisa meningkat. Setelah dilaksanakannya pelaksanaan tindakan siklus II, maka peneliti dan guru mengadakan kegiatan refleksi untuk membahas hal-hal yang terjadi pada pelaksanaan tindakan pada siklus II.

Berdasarkan hasil analisis dan refleksi, bahwa walaupun dalam proses pembelajaran yang dilakukan oleh guru masih ada aspek yang kurang, yaitu pada saat peneliti memberikan tindakan kepada siswa, waktu yang digunakan dalam pembelajaran melebihi waktu pelajaran yang telah terjadwal, namun pada pelaksanaan siklus II sudah mencapai indikator kinerja yang telah ditetapkan. Sehingganya pelaksanaan tindakan tidak dilanjutkan lagi ke siklus berikutnya.

\section{Pembahasan}

Meningkatkan hasil belajar siswa pada materi iman kepada hari akhir sangat tepat apabila digunakan model pembelajaran Mind Mapping (GI). Setelah topik dan permasalahannya disepakati, siswa dan guru menentukan langkah untuk memecahkan masalahnya memberikan dampak besar bagi pengkatan hasil belajar siswa.

Data siklus I tersebut menunjukan ada peningkatan hasil belajar siswa dari observasi awal sampai ke siklus I yaitu $44 \%$ meningkat menjadi $56 \%$. Walaupun terjadi peningkatan, 


$\begin{array}{ll}\text { Volume } & : 05 \\ \text { Nomor } & : 03 \\ \text { Bulan } & : \text { September } \\ \text { Tahun } & : 2019 \\ \text { http } & : \text { //ejurnal.pps.ung.ac.id/index.php/AKSARA/index }\end{array}$

namun belum mencapai indikator kinerja yang sudah ditetapkan. Oleh karena peneliti mengadakan refleksi dengan guru mitra yang menghasilkan beberapa temuan yaitu (a) Penggunaan model Mind Mapping belum efektif; (b) Langkah-langkah kegiatan belajar mengajar dalam menggunakan model Mind Mapping belum efektif dan efisien;(c) Pembagian kelompok belum sempurna(d) Pembelajaran cenderung guru yang lebih agresif dibanding siswa; (e) kurangnya motivasi dan controling, sehingga sebagian siswa hanya bertindak sesuka hati; (f) Belum maksimalnya pemberian tugas; (g) Penyimpulan materi belum efisien; (g) alokasi waktu yang tidak sesuai dengan pembelajaran.

Mencermati data di atas, maka diadakan tindakan kembali yakni siklus II dengan memperhatikan temuan pada siklus I. Hasil siklus II menunjukan bahwa terjadi peningkatan hasil belajar siswa dalam materi iman kepada hari akhir. Hal ini ditunjukan oleh angka prosentase siswa yang mencapai tingkat ketuntasan penguasaan materi makin meningkat dari siklus I sampai pada siklus II yaitu dari 56\% menjadi 96\%. Jika dibandingkan denagan indikator kinerja yang telah ditetapkan untuk dicapai pada penelitian ini yaitu $75 \%$ dari siswa yang dapat menguasai materi dengan tingkat penguasan minimal 75 maka dengan hasil yang telah diperoleh sampai dengan akhir tindakan siklus II menunjukan bahwa indikator kinerja sudah dicapai. Berdasarkan hasil-hasil ini ternyata hipotesis penelitian tindakan yang menyatakan bahwa "jika dalam pembelajaran PAI materi iman kepada hari akhir, guru menggunakan model Mind Mapping maka hasil belajar siswa kelas IX SMPN 4 Kota Gorontalo akan meningkat.", teruji kebenarannya.

\section{PENUTUP}

\section{Simpulan}

Berdasarkan hasil analisis data dan pembahasan yang telah dipaparkan sebelumnya, maka dapat disimpulkan sebagai berikut :

1. Penggunaan model Mind Mapping sangat membantu guru dalam menanamkan materi iman kepada hari akhir pada pembelajaran PAI di Kelas IX SMP Negeri 4 Kota Gorontalo khususnya peningkatan hasil belajar siswa. Hal tersebut ditunjukan oleh hasil-hasil yang diperoleh tindakan siklus I sampai siklus II yang memperlihatkan peningkatan yang cukup baik dalam hal indikator kinerja yang diharapkan tercapai 75 $\%$ memperoleh penguasaan 75 pada postes sesudah tindakan siklus II benar-benar tercapai.

2. Dilaksanakannya penelitian tindakan kelas sampai pada siklus II, karena proses pembelajaran PAI dalam menggunakan model Mind Mapping di siklus I belum mencapai indikator kinerja atau hasil belajar siswa masih rendah. Setelah diperbaiki pada pelaksanaan tindakan siklus II, maka hasil belajar siswa meningkat secara signifikan.

\section{Saran}

Berdasarkan beberapa simpulan tersebut dapat disarankan hal-hal sebagai berikut :

5.2.1 Bagi siswa hendaknya dapat belajar sungguh-sungguh dan aktif dalam pembelajaran tersebut. Selain itu diharapkan kepada siswa untuk dapat mengembangkan pola pikir berdasarkan model Mind Mapping yang dilakukan guru.

5.2.2 Diharapkan kepada guru dapat melaksanakan penelitian tindakan kelas yang serupa untuk pokok-pokok bahasan yang lain dalam pembelajaran PAI guna perbaikan dan peningkatan kualitas proses pembelajaran.

5.2.3 Pihak sekolah hendaknya hasil penelitian ini dapat dijadikan salah satu aspek dalam perencanaan pada tahun berikutnya. Selain itu, diharapkan kepada pihak sekolah untuk dapat memediasi guru untuk memahami dan mempelajari metode atau model yang baik untuk diterapkan. 


$\begin{array}{ll}\text { Volume } & : 05 \\ \text { Nomor } & : 03 \\ \text { Bulan } & : \text { September } \\ \text { Tahun } & : 2019 \\ \text { http } & : \text { //ejurnal.pps.ung.ac.id/index.php/AKSARA/index }\end{array}$

5.2.4 Bagi peneliti yang lainnya hendaknya dapat mengembangkan penelitian yang telah ada.

\section{DAFTAR PUSTAKA}

Djamarah Bahri Syaiful Drs dan Zain Aswan Drs. 2010. Strategi Belajar Mengajar. Rineka Cipta: Jakarta

Bobbi DePorter dan Mike Hernacki. 2002. Quantum Learning: Membiasakan belajar Nyaman dan Menyenangkan, Terj. Alwiyah Abdurrahman, Bandung: Kaifa,

Hisnu Tantya dan Winardi. 2008. E-Book Ilmu Pengetahuan Sosial Untuk Kelas IV. Pusat Perbukuan, Departemen Pendidikan Nasional: Jakarta

Nasution Harun. Islam Ditinjau dari Berbagai Aspeknya. Jakarta: UI Press

Rusman. 2012. Model-Model Pembelajaran. Mengembangkan Profesionalisme Guru. Edisi II. PT. Raja Grafindo Persada: Jakarta

Sadiman Sadad Irawan dan Amalia Shendy.2008. E-Book Ilmu pegetahuan sosial 4: SD/MI kelas IV. Pusat Perbukuan, Departemen Pendidikan Nasional: Jakarta

Samatowa, Usman. 2009. Daya Pikir, Daya Cipta. PT. @ ndragogika Press: Gorontalo.

Sholeh Abdul Azis dan Abdul Azis Madjid. 2001. Tarbiyah Wa Turuqu At-Tadris, Jus. 1. Makkah : Darul Ma'rif

Slameto, Drs. 2010. Belajar dan Faktor-Faktor Yang Mempengaruhinya. Rineka Cipta: Jakarta Siddiq Djauhar dkk. 2009. Pengembangan Bahan Pembelajaran SD. Dirjen Pendidikan Tinggi Depdiknas.

Suprijono Agus. 2012. Cooperative Learning. Pustaka Pelajar:Yogyakarta

Trianto. 2007. Model-model Pembelajaran Inovatif Berorientasi Konstruktivistik: Konsep, Landasan Teoritis-Praktis dan Implementasinya,Jakarta: Prestasi Pustaka.

Uno B Hamzah, M.Pd Dr. 2011. Teori Motivasi dan Pengukurannya Analisis Di Bidang Pendidikan. PT Bumi Aksara: Jakarta. 